\title{
Лiтература:
}

1. A USA AGRICULTURAL PERSPECTIVE Mike Dunn. URL: http://ageconsearch.umn.edu/bitstream/17325/1/ar720029.pdf.

2. Мезенцева Е.С. Государственое регулирование АПК в развитых странах Вестник СевКавГТУ, Серия «Экономика». 2004. № 1 (12). URL: http://science.ncstu.ru/articles/econom/12/37.pdf/file_download].

3. Назаренко В. И., Папцов А. Г. Державне регулювання сільського господарства в державах 3 развинутою економікою. М. : Інформагробізнес, 1996.

4. Аграрне право України Підручних для студентів юридичних спеціальностей виших закладів освіти / В. М. Гайворонський, В. П. Жушман, В. М. Корнієнко та ін.; За ред. В. М. Гайворонського та В. П. Жушмана. Х.: Право, 2003. 240 с.

5. Лебедева О. Державне регулювання сільського господарства в США. АПК : економіка управління. 1996. № 7. С. 73-7.

6. CONTROL BY GOVERNMENT Robert G. F. Spitze Professor of Agricultural Economics University of Illinois URL: http://www.dwaf.gov. za/wfw/Docs/Papers/A\%20USA\%20AGRICULTURAL\%20PERSPECTIVE. doc.

DOI https://doi.org/10.30525/978-9934-26-179-4-25

\section{ЩОДО ЗАБОРОНИ ВИКОРИСТАННЯ ТВАРИН У РОЗВАЖАЛЬНИХ ЦІЛЯХ АБО У ВИДОВИЩНИХ ЗАХОДАХ}

\author{
Ковальчук Л. В. \\ студентка III курсу юридичного факультету \\ Науковий керівник: Липницька Є. О. \\ кандидат юридичних наук, дочент, \\ доиент кафедри господарського та адміністративного права \\ юридичного факультету \\ Донечький начіональний університет імені Василя Стуса \\ м. Вінниия, Украӥна
}

Однією 3 найулюбленіших вистав для дітей $є$ циркові трюки, виконані як професійними артистами, так і добре дресированими тваринами. Милі та слухняні тварини захоплюють аудиторію та 
породжують попит на даний вид мистецтва. Проте за красивою картинкою ховається біль та страждання сотень поневолених істот. Задля чітко виконаного трюку кожна тварина проходить через години жорстоких дресировок, а показова слухняність на сцені - лише страх перед можливими катуваннями. 3 огляду на це постає нагальна потреба в дослідженні законодавства в сфері захисту тварин та виділенні конкретних напрямів удосконалення такого захисту з метою подолання вказаних проблем.

Дана тема була предметом дослідження таких науковців як П. Грудєва, Д. Змієнко, Ю. Пожарської, К. Станіславської, Є. Кузнєцової, Ю. Дмитрієва тощо. Проте досі існує потреба у дослідженні проблем забезпечення належного нормативного регулювання захисту тварин. Свропейський Союз $\epsilon$ прикладом відносно ефективної організації захисту тварин. Більшість країн СС вже прийняли загальнонаціональні заборони щодо використання диких тварин у цирках. Тому нині є необхідність приведення законодавства у відповідність євроінтеграційним процесам ЄС задля наближення України до високорозвинених країн світу.

Метою дослідження $\epsilon$ аналіз чинного законодавства щодо захисту тварин від жорстокого поводження та обгрунтування доцільності повної заборони їх використання у розважальних цілях або у видовищних заходах.

В Україні боротьба за заборону цирків з тваринами йде вже багато років. Незважаючи на викривальні відео у відкритому доступі інтернету з показом жорстоких методів дресирування циркових тварин, неналежних умов утримання, жахливого перевезення циркових тварин, масові акції протесту, численні петиції з сотнями тисяч підписів, законодавчу машину поки ще не вдалося зрушити 3 мертвої опори, а законотворчий процес запустити у поступово напрямку заборони використання тварин у видовищних заходах [1].

На початку 2019 до Верховної Ради України був поданий проект Закону «Про внесення змін до деяких законодавчих актів України щодо удосконалення законодавства з питань захисту тварин від жорстокого поводження» № 9453-1, який регламентував питання заборони цирків, проте його було відкликано [2]. На сьогодні у парламенті на стадії доопрацювання за висновками Комітету знаходиться ще один законопроект щодо заборони використання тварин у цирку та інших незаконних видовищних заходах із залученням тварин № 5409 від 21.04.2021p., який передбачає повну заборону цирків 31 січня 2022 року. Але на разі складно стверджувати, чи зможе він вступити у дію до даної дати [3]. 
Хоча сьогодні на законодавчому рівні і немає заборони на цирки, проте окремі українські міста, зокрема Київ, Дніпро, Івано-Франківськ, Черкаси, Ужгород, Рівне, Луцьк, Кам'янське, Ірпінь, Ковель, Канів, Богородчани, Бориспіль, Боярка, Дрогобич самостійно на місцевому рівні встановлюють обмеження їх діяльності. Прикладом також слугує значний перелік країн, які вже заборонили цирки, зокрема повна заборона на цирки з тваринами діє в Австрії, Бельгії, Великій Британії, Греції, Словенії, Хорватії, часткова - у США, Аргентині, Німеччині, Польщі, Бразилії, Австралії, Китаї тощо. Тому це питання є вкрай важливим на рівні усієї країни, а не лише в її окремих частинах $[4$, с. 99].

Правову основу, що регулює правовідносини щодо використання та охорони об'єктів тваринного світу, як в стані волі, так і різних видів утримання, складають наступні закони. Зокрема, в статті 2 Закону України «Про тваринний світ», визначено завдання законодавства України про охорону, використання і відтворення тваринного світу, до яких належать: регулювання відносин у галузі охорони, використання i відтворення об'єктів тваринного світу; збереження та поліпшення середовища існування диких тварин; забезпечення умов збереження всього видового і популяційного різноманіття тварин [5].

Спеціальні норми містяться у Законі України «Про захист тварин від жорстокого поводження», статті 8, 11, 18 та 25 якого регулюють основні питання стосовно утримання, транспортування тварин, поводження з ними тощо [6]. Проте у даному Законі відсутні норми щодо заборони використання тварин у розважальних установах, які, наприклад, наявні у законодавстві Болгарії [2]. Натомість кількість правопорушень у вказаній сфері щоденно збільшується. В період з 01.01.2020 року до 01.05.2020 року, навіть в умовах карантину, судами України було винесено 11 вироків у справах про жорстоке поводження з тваринами у цирках, з яких 2 - за наслідками перегляду справи в апеляційній інстанції. Станом на 01.05.2020 року з цих вироків вже 6 набули законної сили [7]. I це лише за декілька місяців.

Окрім негативної статистики $\epsilon$, звичайно, позитивні рішення. До прикладу, рішення апеляційного суду від 06.02.2019 р. № 161/6060/17 [8]. 01.12.2016 року Луцькою міською радою було прийнято рішення «Про заборону пересувних цирків, які використовують у своїй діяльності тварин». Позивач, ПП «Продюсерський центр «Гастролі в Україні» - власник цирку, вважав, що дане рішення зачіпає його права, прийняте 3 порушенням норм матеріального права. Суд першої інстанції визнав протиправним та скасував рішення Луцької міської ради, проте 6 лютого 2019 р. колегія суддів Восьмого ААС розглянула апеляційну скаргу Рівненської міської ради на рішення Рівненського 
окружного адміністративного суду, за якою суд постановив, що заборона розміщення на території міста Рівного пересувних і мобільних цирків з тваринами та звіринців належить до повноважень міської ради щодо управління у сфері захисту тварин від жорстокого поводження на відповідній території, що випливає із приписів частин 2 і 3 ст. 28 Закону «Про захист тварин від жорстокого поводження» [6]. Тобто в даному випадку вдалося відстояти право на заборону цирків і вказане рішення слугує позитивним прикладом змін у світогляді суспільства та готовність до повної заборони таких заходів із залученням тварин.

Отже, з вищевказаного можна зробити висновок, що проект Закону «Про внесення змін до деяких законодавчих актів України щодо заборони використання тварин у цирку та інших незаконних видовищних заходах із залученням тварин» $є$ необхідним та вагомим для нашого суспільства. Його метою є повна заборона 31 січня 2022 року на використання тварин у циркових виставах та інших незаконних видовищних заходах із залученням тварин, в тому числі виставок тварин, що постійно гастролюють. В законопроекті пропонується встановити заборону на такі видовищні заходи із залученням тварин: контактний зоопарк, пересувний звіринець, бої тварин (собачі, півнячі і т.д.), нацьковування тварин одна на одну, циркові виступи із залученням тварин (стаціонарний цирк, пересувний цирк, цирк на сцені, цирк-шапіто). А публічна демонстрація тварин в зоопарках, регіональних центрах порятунку і реабілітації диких тварин дозволена виключно з метою ознайомленням з біорізноманіттям нашої планети i виключає показ можливостей тварин до дресури та має на меті виховання гуманного ставлення до тварин.

Заборона на використання тварин в цирках, на думку авторів законопроекту, стане стимулом вдосконалення всієї циркової системи, так як виникне необхідність впровадження сучасних технологій в циркові шоу програми та розвитку нових напрямків циркового мистецтва.

Можна стверджувати, що сьогодні в Україні недосконале правове регулювання у сфері використання тварин в розважальних цілях. Як бачимо з практики, тваринам доводиться проходити через жорстокі катування аби задовольнити публіку. Тому нагальною потребою $є$ прийняття вищевказаного Закону . Крім цього необхідно врегулювати питання контролю за діяльністю цирків та відповідальність за незаконне використання тварин у видовищних заходах, закріпити процедуру передачі тварин у Центр порятунку і реабілітації диких тварин, визначити органи, до компетенції яких буде відноситися питання передачі тварин та контроль належності умов їх утримання. 
Саме даний комплекс заходів стане важливим етапом розвитку гуманного суспільства та наблизить Україну до високорозвинених країн світу.

\section{Література:}

1. Пояснювальна записка до проекту Закону України «Про внесення змін до деяких законодавчих актів України щодо заборони використання тварин у цирку та інших незаконних видовищних заходах із залученням тварин» від 20.04.2021 p. № 299д9/12021/134877. Ліга Закон. URL: http://search.ligazakon.ua/1_doc2.nsf/ link1/GI04956A.html (дата звернення: 22.11.2021).

2. Про внесення змін до деяких законодавчих актів України щодо удосконалення законодавства 3 питань захисту тварин від жорстокого поводження: проект Закону від 16.01.2019p. № 9453-1. Верховна Рада Украӥни: офіційний веб-портал. URL: http://w1.c1.rada.gov.ua/ pls/zweb2/webproc4_1?pf3511=65344

3. Про внесення змін до деяких законодавчих актів України щодо заборони використання тварин у цирку та інших незаконних видовищних заходах із залученням тварин: проект Закону від 21.04.2021 p. № 5409. Верховна Рада Украӥни: офіиійний веб-портал. URL: http://w1.c1.rada.gov.ua/pls/zweb2/webproc4_1?pf3511=71740 (дата звернення: 22.11.2021).

4. Змієнко Д. М., Грудєв П. Х. Еколого-правові аспекти захисту тварин в Україні. Екологічна політика. 2019. № 5. С. 98-103.

5. Про тваринний світ: Закон України від 13.12.2001p. № 2894-III. Відомості Верховної Ради України. 2002. № 14. Ст.97 (із змінами).

6. Про захист тварин від жорстокого поводження: Закон України від 21.02.200Р. № 3447-IV. Відомості Верховної Ради України. 2006. № 27. Ст.230 (із змінами).

7. Вироки у справах про жорстоке поводження 3 тваринами за 2020 рік. Юридична газета. URL: https://yur-gazeta.com/golovna/virokiu-spravah-pro-zhorstoke-povodzhennya-z-tvarinami-za-2020-rik1.html (дата звернення: 22.11.2021).

8. Рішення Луцького міськрайонного суду Волинської області від 21 червня 2017 p. № 161/6060/17. URL: https://zakononline.com.ua/ court-decisions/show/67382741 (дата звернення: 22.11.2021). 